\title{
WINNING AND KEEPING POWER IN CANADIAN POLITICS
}

Do negative campaigns win elections? Do voters abandon candidates accused of scandalous behaviour? Do government apologies affect prospects for re-election? While many people assume the answer to each of these questions is yes, there is limited empirical evidence to support these assumptions. In this book, Jason Roy and Christopher Alcantara use a series of experiments to test these and other commonly held beliefs.

Each chapter draws upon contemporary events and literature to frame the issues and strategies. The findings suggest that not all of the assumptions that people have about the best strategies for winning and keeping political power hold up to empirical scrutiny. In fact, some work in ways that many readers may find surprising.

Original and innovative in its use of experimental methods, Winning and Keeping Power in Canadian Politics is a persuasive analysis of some of our most prominent and long-standing political myths. It will be a "go to" resource for journalists, strategists, scholars, and general readers alike.

JASON ROY is an associate professor in the Department of Political Science at Wilfrid Laurier University.

CHRIstopher Alcantara is a professor in the Department of Political Science at Western University. 



\section{Winning and Keeping Power in Canadian Politics}

JASON ROY AND CHRISTOPHER ALCANTARA

UNIVERSITY OF TORONTO PRESS

Toronto Buffalo London 
(C) University of Toronto Press 2020

Toronto Buffalo London

utorontopress.com

Printed in the U.S.A.

ISBN 978-1-4875-0731-2 (cloth) ISBN 978-1-4875-3600-8 (EPUB)

ISBN 978-1-4875-2501-9 (paper) ISBN 978-1-4875-3599-5 (PDF)

\section{Library and Archives Canada Cataloguing in Publication}

Title: Winning and keeping power in Canadian politics / Jason Roy and Christopher Alcantara.

Names: Roy, Jason J., 1974- author. | Alcantara, Christopher, 1978- author.

Description: Includes bibliographical references and index.

Identifiers: Canadiana (print) 20200209426 | Canadiana (ebook) 20200209450 |

ISBN 9781487525019 (softcover) | ISBN 9781487507312 (hardcover) |

ISBN 9781487536008 (EPUB) | ISBN 9781487535995 (PDF)

Subjects: LCSH: Political campaigns - Canada. | LCSH: Elections - Canada. |

LCSH: Canada - Politics and government. | LCSH: Politics, Practical Canada.

Classification: LCC JL193 .R69 2020 | DDC 324.70971-dc23

This book has been published with the help of a grant from the Federation for the Humanities and Social Sciences, through the Awards to Scholarly Publications Program, using funds provided by the Social Sciences and Humanities Research Council of Canada.

University of Toronto Press acknowledges the financial assistance to its publishing program of the Canada Council for the Arts and the Ontario Arts Council, an agency of the Government of Ontario.

Canada Council for the Arts

Funded by the Government gouvernement of Canada du Canada
Conseil des Arts du Canada
ONTARIO ARTS COUNCIL CONSEIL DES ARTS DE L'ONTARIO

an Ontario government agency an Ontario government agency
un organlsme du gouvernement de l'Ontario

\section{Canadä}


In memory of Barry Kay 
